\title{
UTAUT APPROACH APPLICATION TO ANALYZE THE DETERMINANTS OF FINTECH MARKET AGGREGATOR USER SATISFACTION
}

\author{
Theodora Regina ${ }^{1}$, Florentina Kurniasari ${ }^{2}$, Prio Utomo ${ }^{3}$ \\ \{iamtheodoraregina@gmail.com ${ }^{1}$, florentina@umn.ac.id ${ }^{2}$, prio.utomo@umn.ac.id $\left.{ }^{3}\right\}$ \\ Technology Management Department, Universitas Multimedia Nusantara ${ }^{1,2,3}$
}

\begin{abstract}
Fintech Market Aggregator (FMA) gather information, and compare financial product offers from various banks or non-bank institution which help the customer to decide which product that fit their needs that support financial literation in Indonesia. This research aims to analyze the determinant factors of FMA user satisfaction using the UTAUT approach that still limited to be found and enriched by the trust variable. The study used an online questionnaire from 90 FMA users, analyzed by SEM method and SMART PLS application. The result showed that performance expectancy, effort expectancy, and social influence had a positive impact on the use of FMA services. The use of FMA had a positive effect on user satisfaction. The usage of the UTAUT model on this research could explain that all the variables had a 71.6 percent influence on to use of FMA. And the use of FMA services influenced user satisfaction of 45.4 percent.
\end{abstract}

Keywords: fintech market aggregator, UTAUT, user satisfaction, SEM, fintech

\section{$1 \quad$ Introduction}

Data from the World Bank [1] showed that Indonesia has lower financial inclusion compare to Singapore, Malaysia, China, Thailand, and other countries. Only 35 percent of Indonesian has a bank account in a financial institution with 26.6 percent of them had a saving account in the financial institution, and only 13.1 percent get a loan from a financial institution. Besides, the credit card user only 1.7 percent and insurance 11.8 percent, which also relatively low compared to other countries.

The growth of fintech services was supported by the growing numbers of internet users in Indonesia. The fintech services were categorized as payment and transfer services, alternative online lending, block chain, market aggregator, etc. Fintech market aggregator (FMA) gathered all related available information about the benefits, facilities, protection, and the price of product and services which offered from financial institution both banks or nonbanks. FMA enabled the user to apply and get the product or services offered by financial institution based on their customized needs. But the FMA users are still limited that only 12.59 percent use the FMA services [2].

The purpose of this research is to find answer to the question of what factors determined FMA users and user's satisfaction. This research uses the UTAUT approach and enriched with trust variable for the determinant factors of fintech market aggregator user satisfaction. UTAUT has 0.69 percent to describe the acceptance of new technology. This research use performance expectancy, effort expectancy, social influence, facilitating condition variable, elaborate with trust variable and user satisfaction. The result of this research is to recommend the strategy to improve the quality of FMA services, to increase the FMA users which could increase the users of bank and non-bank products and increase the financial inclusion and literation in Indonesia.

\section{$2 \quad$ Literature Review}

The gap of this research is to examine the determinants of users and user satisfaction of FMA while bank and non-bank products still have a limited number of users. We hope that with more user use the FMA services can increase more user to use bank and non-bank products in Indonesia. This research analyze the factors of FMA users that had a positive impact on the use and satisfaction to increase new users.

Digital financial services (DFS) was defined as financial services that accessed and delivered through a digital channel in payment, credit, deposit, saving, loans, transfer, insurance, and other mobile financial services [3]. The digital channel refers to the internet, pos terminals, ATMs, mobile phones, NFC-enabled devices, electronically enabled cards, tablets, and other digital systems. DFS model usually uses agents and third-party intermediaries for the network to improve accessibility and lower the delivery cost. 
Meanwhile, financial technology is defined as the financial system that used technology and has products, services, and new model business which could impact to monetary stability, financial system stability which has function on efficiency, security, and reliable payment system.

Fintech market aggregator (FMA) referred to fintech services which provide the information and comparison of bank and non-bank financial products and services based on customer's needs [4]. There are 14 registered fintech aggregator [5] and 25 newly registered as aggregator business model in Indonesia [4].

UTAUT (Unified Theory of Acceptance and Use of Technology) is a theoretical model to measure the success of acceptance of new technology and was formulated by Venkatesh and others. UTAUT could explain user intention to use an information system and subsequent usage behavior [6]. There are four variables of UTAUT that had been used in this research, namely: performance expectancy, effort expectancy, social influence, and facilitating conditions.

Performance expectancy defined as the degree to which an individual believes that using the system will help to attain gains in job performance [6]. Based on Chikondi Daka's research [7], performance expectancy has a significant impact on the adaptation of e-banking services. Effort expectancy defined as the degree of ease associated with the use of the system [6]. Based on Chikondi Daka's research [7], effort expectancy has a significant impact on the adaptation of e-banking services. Social influence defined as the degree to which an individual perceives that the other's effect as a direct determinant [6]. Another research also stated that social influence has a significant impact on the use of e-government services [8]. While facilitating conditions defined as the degree to which an individual believes that an organizational and technical infrastructure exists to support the use of the system. He also explained that facilitating conditions has a significant impact on the use of behavior [6].

Trust was known as one of the factors for customers to use the new technology [9]. Trust is defined as the perception of a student in the reliability and trustworthiness of the services offered by cloud service providers [10] and has a significant impact on the use of mobile cloud service. Trust also becomes the main factor in adopting mobile banking because it involves the user's private data and fund [11]. Therefore, trust became one of the important variables for an institution with online based [12].

User satisfaction is an evaluation of user and effective response of experience on using the information technology. Research from Chiu shown that the use of m-learning website based has a positive impact on user satisfaction [13]. User satisfaction becomes user evaluation and effective responses to experiencing information technology. User satisfaction also becomes the comparison of user expectations [14] and the result of using information technology. User satisfaction becomes one of the most important things to be maintained for the customer [15]. Satisfaction is the consumer's fulfillment response or judgment of a product/service that providing a pleasurable level of fulfillment [16]. From the explanation of the literature review above, this research was able to develop a conceptual framework as on Figure 1.

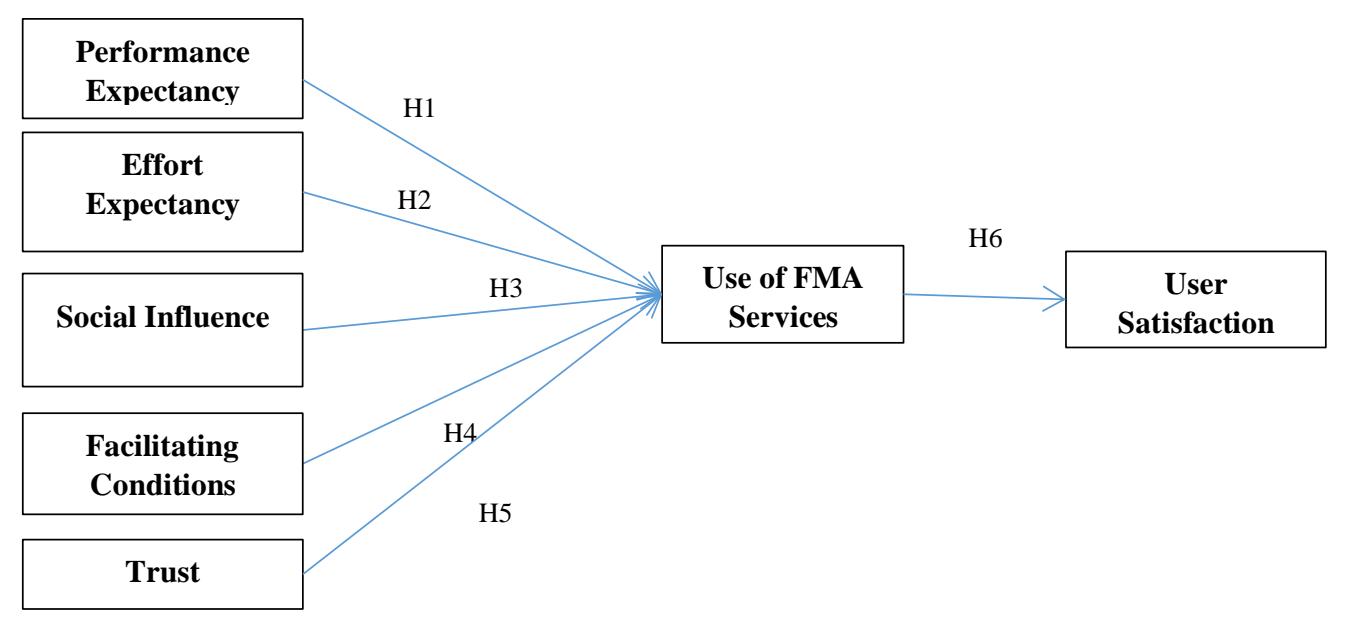

Fig 1. Research Theoretical Framework.

The following hypotheses of this research were developed by the research theoretical framework as described in Figure 1: 
$\mathrm{H}_{1}$ : Performance expectancy (PE) has a positive effect on the use of fintech market aggregator services (UF)

$\mathrm{H}_{2}$ : Effort expectancy (EE) has a positive effect on the use of fintech market aggregator services (UF)

$\mathrm{H}_{3}$ : Social influence (SI) has a positive effect on the use of fintech market aggregator services (UF)

$\mathrm{H}_{4}$ : Facilitating conditions (FC) have a positive effect on the use of fintech market aggregator services (UF)

$\mathrm{H}_{5}$ : Trust (TR) has a positive effect on the use of fintech market aggregator services (UF)

$\mathrm{H}_{6}$ : Use of fintech market aggregator services (UF) has a positive effect on user satisfaction (US)

\section{$3 \quad$ Methodology and Data Analysis}

\subsection{Methodology}

This research is quantitative research with hypotheses testing to find the determinant factors of fintech market aggregator user satisfaction. The online questionnaires in 5 Likert Scale were distributed among the respondents who were users of fintech market aggregator in Indonesia with the age range at 17-54 years old. All the data were analyzed using the statistical tools Partial Least Squares SEM (PLS-SEM) method [17]. PLS-SEM is used for theory confirmation and explains if there was a relation between the latent variable [18]. PLS-SEM also used in quantitative research for a model that involves latent variables with some indicators [19].

\subsection{Data Analysis}

This research was able to collect 194 respondents, but only 90 respondents met the requirements develop by the researcher. The demographic data in Table 1 showed that 62 respondents are male, with 46 percent of respondents are in age 26-35 years old and 76 percent of respondents earned a bachelor's degree.

Table 1. Demographics of Respondents.

\begin{tabular}{clcc}
\hline & \multicolumn{1}{c}{ Option } & Frequency & $\%$ \\
\hline \multirow{4}{*}{ Gender } & Male & 62 & $69 \%$ \\
& Female & 28 & $31 \%$ \\
Age & $17-25$ & 24 & $27 \%$ \\
& $26-35$ & 41 & $46 \%$ \\
& $36-45$ & 21 & $23 \%$ \\
& $46-54$ & 4 & $4 \%$ \\
& High School & 14 & $16 \%$ \\
& Bachelor & 68 & $76 \%$ \\
& Master & 7 & $8 \%$ \\
& Doctoral & 1 & $1 \%$ \\
\hline \multirow{6}{*}{}
\end{tabular}

\section{$4 \quad$ Research Result and Discussion}

The result of validation and reliability for 90 respondents are shown below on Table 2 . 
Table 2. Reliability and Validity.

\begin{tabular}{|c|c|c|c|c|c|c|c|}
\hline \multirow{3}{*}{ Latent Variable } & \multirow{3}{*}{ Indicators } & \multirow{3}{*}{$\begin{array}{c}\begin{array}{c}\text { Convergent } \\
\text { Validity }\end{array} \\
\text { AVE } \\
>0.50\end{array}$} & \multirow{2}{*}{$\begin{array}{c}\begin{array}{c}\text { Discriminant } \\
\text { Validity }\end{array} \\
\text { Outer } \\
\text { Loading }\end{array}$} & \multirow{3}{*}{$\begin{array}{c}\text { Model } \\
\text { Evaluation }\end{array}$} & \multicolumn{2}{|c|}{$\begin{array}{c}\text { Internal Consistency } \\
\text { Reliability }\end{array}$} & \multirow{3}{*}{$\begin{array}{c}\text { Model } \\
\text { Evaluation }\end{array}$} \\
\hline & & & & & $\begin{array}{l}\text { Composite } \\
\text { Reliability }\end{array}$ & $\begin{array}{l}\text { Cronbach's } \\
\text { Alpha }\end{array}$ & \\
\hline & & & $>0.60$ & & $>0.60$ & $>0.60$ & \\
\hline \multirow{4}{*}{$\begin{array}{c}\text { Performance } \\
\text { Expectancy }(\mathrm{PE})\end{array}$} & PE1 & \multirow{4}{*}{0.593} & 0.715 & Valid & \multirow{4}{*}{0.853} & \multirow{4}{*}{0.773} & \multirow{4}{*}{ Reliable } \\
\hline & PE2 & & 0.783 & Valid & & & \\
\hline & PE3 & & 0.771 & Valid & & & \\
\hline & PE4 & & 0.810 & Valid & & & \\
\hline \multirow{3}{*}{$\begin{array}{c}\text { Effort } \\
\text { Expectancy (EE) }\end{array}$} & EE1 & \multirow{3}{*}{0.594} & 0.807 & Valid & \multirow{3}{*}{0.813} & \multirow{3}{*}{0.657} & \multirow{3}{*}{ Reliable } \\
\hline & EE2 & & 0.653 & Valid & & & \\
\hline & EE3 & & 0.840 & Valid & & & \\
\hline \multirow{3}{*}{$\begin{array}{l}\text { Social Influence } \\
\text { (SI) }\end{array}$} & SI1 & \multirow{3}{*}{0.804} & 0.856 & Valid & \multirow{3}{*}{0.925} & \multirow{3}{*}{0.878} & \multirow{3}{*}{ Reliable } \\
\hline & SI2 & & 0.916 & Valid & & & \\
\hline & $\mathrm{SI} 3$ & & 0.916 & Valid & & & \\
\hline \multirow{4}{*}{$\begin{array}{c}\text { Facilitating } \\
\text { Conditions (FC) }\end{array}$} & $\mathrm{FC} 1$ & \multirow{4}{*}{0.625} & 0.826 & Valid & \multirow{4}{*}{0.868} & \multirow{4}{*}{0.799} & \multirow{4}{*}{ Reliable } \\
\hline & $\mathrm{FC} 2$ & & 0.644 & Valid & & & \\
\hline & FC3 & & 0.846 & Valid & & & \\
\hline & $\mathrm{FC} 4$ & & 0.829 & Valid & & & \\
\hline \multirow{3}{*}{ Trust (TR) } & TR1 & \multirow{3}{*}{0.669} & 0.799 & Valid & \multirow{3}{*}{0.858} & \multirow{3}{*}{0.751} & \multirow{3}{*}{ Reliable } \\
\hline & TR2 & & 0.778 & Valid & & & \\
\hline & TR3 & & 0.875 & Valid & & & \\
\hline & UF1 & & 0.715 & Valid & & & \\
\hline Market & UF2 & 0.575 & 0.738 & Valid & 0.802 & 0.628 & Reliable \\
\hline & UF3 & & 0.817 & Valid & & & \\
\hline User & US1 & & 0.932 & Valid & & & \\
\hline Satisfaction & US2 & 0.712 & 0.922 & Valid & 0.878 & 0.787 & Reliable \\
\hline & US3 & & 0.645 & Valid & & & \\
\hline
\end{tabular}

Table 2 showed that all the indicators are valid and reliable since all indicators had a score of AVE $>0.50$ which social influence variable had the highest value. The value of outer loading for all variables had a score $>0.60$ with the US1 has the highest value. The data showed that all indicators had a score of Composite Reliability $>0.60$ with the social influence variable had the highest score. Furthermore, all variables had a Cronbach Alpha value $>0.60$ with the social influence variable has the highest score. It could be concluded that all the variables used in this research were valid and reliable. 


\section{Hypothesis Result}

The next figure showed the $t$-value of each indicator that showed the $\mathrm{R}^{2}$ value on Figure 2.

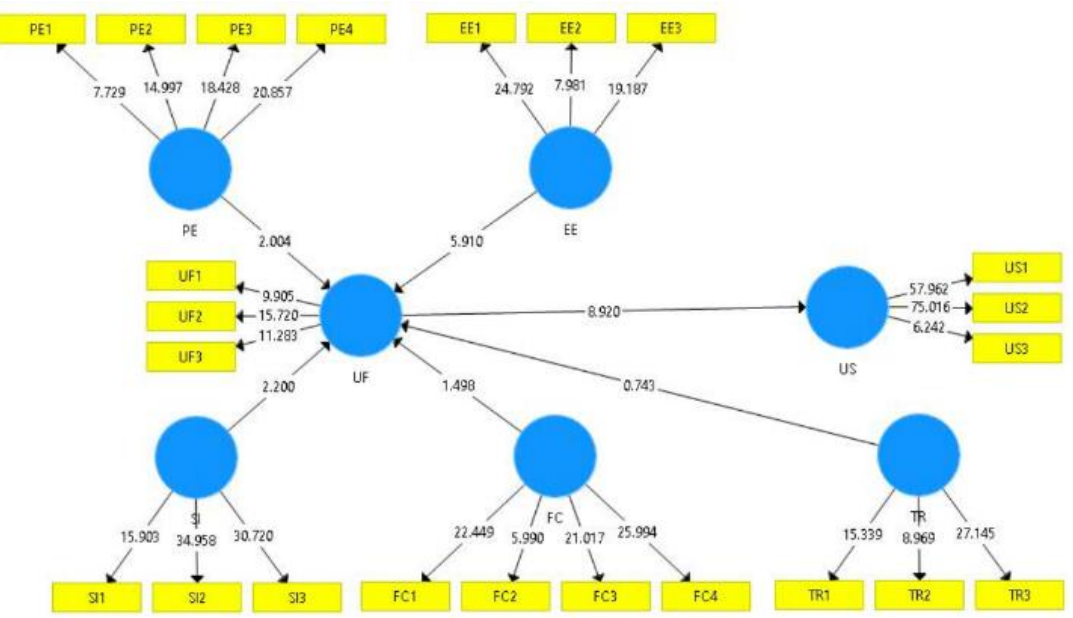

Fig 2. T-value of each indicator.

The result of hypothesis testing showed that the $\mathrm{R}^{2}$ value of the use of Fintech Market Aggregator (UF) was 0.716 and the $\mathrm{R}^{2}$ value of User Satisfaction (US) was 0.454. It meant that performance expectancy, effort expectancy, social influence, facilitating conditions, and trust had a contribution of 71.6 percent to explain the use of fintech market aggregator. Meanwhile, the use of fintech market aggregator had a contribution of 45.4 percent to explain user satisfaction. The path coefficients for this research is explained on the table 3.

Table 3. Path Coefficients (Mean, STDEV, T-Values \& P-Values).

\begin{tabular}{|c|c|c|c|c|c|}
\hline & $\begin{array}{c}\text { Original } \\
\text { Sample } \\
(\mathbf{O})\end{array}$ & $\begin{array}{c}\text { Sample } \\
\text { Mean } \\
(\mathbf{M})\end{array}$ & $\begin{array}{c}\text { Standard } \\
\text { Deviation } \\
(\text { STDEV })\end{array}$ & $\begin{array}{c}\text { T Statistics } \\
(\mid \mathbf{O} / \text { STEDV|) }\end{array}$ & P Value \\
\hline PE -> UF & 0.162 & 0.165 & 0.081 & 2.004 & 0.046 \\
\hline EE -> UF & 0.494 & 0.489 & 0.084 & 5.910 & 0.000 \\
\hline SI -> UF & 0.180 & 0.185 & 0.082 & 2.200 & 0.028 \\
\hline FC -> UF & 0.161 & 0.166 & 0.108 & 1.498 & 0.135 \\
\hline TR -> UF & 0.078 & 0.080 & 0.105 & 0.743 & 0.458 \\
\hline UF -> US & 0.674 & 0.682 & 0.076 & 8.920 & 0.000 \\
\hline
\end{tabular}

Table 3 showed that performance expectancy, effort expectancy, and social influence had a positive impact on the use of fintech market aggregator $(t>1.96 ; \mathrm{p}<0.05)$. The use of fintech market aggregator also had positive impact on user satisfaction $(t>1.96 ; \mathrm{p}<0.05)$. While the facilitating conditions and trust are had no impact on the use of fintech market aggregator $(\mathrm{t}<1.96 ; \mathrm{p}>0.05)$.

$\mathrm{H}_{1}$ : Performance expectancy (PE) has a positive effect on the use of fintech market aggregator services (UF).

The hypothesis testing showed that $\mathrm{H}_{1}$ was accepted since the $\mathrm{p}$-value showed 0.046 ( $\mathrm{p}$-value $<0.005$ ). Performance expectancy could be enhancing productivity, effectiveness, simplifying the process, and increasing the quality of services. It is also supported by the result of interviews with some FMA providers who state that FMA is created as an online channel aim to accelerate and facilitate users by providing an accurate, complete, and appropriate comparison of financial product information. It is also supported by previous research who mentioned that performance expectancy (PE) has a positive effect on behavioral intention of e-banking service. [7].

$\mathrm{H}_{2}$ : Effort expectancy (EE) has a positive effect on the use of fintech market aggregator services (UF).

Table 3 also mentioned that $\mathrm{H}_{2}$ was accepted which was shown by the $\mathrm{p}$-value of 0.000 (p-value $<0.005$ ). Effort expectancy which defined as the degree of ease associated with the use of the system [6] has a positive effect on the use of fintech market aggregator services. Easier to use, customer service availability, and easy features to access are the reasons why they use FMA services. It is also supported by previous research which shows that effort expectancy has a positive effect on the use of Zakat and Waqf behavior [20].

H3: Social influence (SI) has a positive effect on the use of fintech market aggregator services (UF). 
Based on hypothesis testing on table 3 show that $\mathrm{H}_{3}$ was accepted because had a p-value of 0.028 (p-value < 0.005). A social influence which defined as the degree to which an individual perceives that important others believe so they use the new system [6] has a positive effect on the use of fintech market aggregator services. It is also supported by Ji-Hwan Lee's result that social influence has a significant effect on Certified e-Document Authority (CeDA) use behavior in the Republic of Korea. Senior management, influential people, important people, and climate of the organization have a significant effect on CeDA use behavior in Republic Korea [9]. It can also describe from Hofstede's view, Indonesia and Korea have a low individualism score. Individualism is defined as the degree of interdependence a society maintains among its members [21]. Indonesia is a collectivist society which means has a high preference for a strongly defined social framework in which individuals are expected to conform to the ideals of the society and the groups to which they belong.

$\mathrm{H}_{4}$ : Facilitating conditions (FC) have a positive effect on the use of fintech market aggregator services (UF).

Based on hypothesis testing on the table above show that $\mathrm{H}_{4}$ was rejected because had the p-values of 0.135 (p-value > 0.005). Facilitating conditions which defined as the degree to which an individual believes that an organizational and technical infrastructure exists to support the use of the system [6] has no significant effect on the use of fintech market aggregator services. It is also supported by Huey-Yeh Lin's research show that facilitating conditions has no significant effect on the mobile payment system in Taiwan (Lin et al., 2019).

H$_{5}$ : Trust (TR) has a positive effect on the use of fintech market aggregator services (UF)

Based on hypothesis testing on the table above show that $\mathrm{H}_{5}$ was rejected (p-value > 0.005). Trust has no significant effect on the use of fintech market aggregator services. It is also supported by previous research that trust has no significant effect on the use of m-fashion application intention in Sweden [23]. Other research also shows supported this result that the trust variable has no significant effect on equity crowd-funding behavioral intention in Indonesia [24]. From Hofstede's view, uncertainty avoidance can be used as a dimension to support this research result. Uncertainty avoidance is defined as to which the members of a culture feel threatened by ambiguous or unknown situations and have created beliefs and institutions that try to avoid [21]. Indonesia has a low score or low preference for avoiding uncertainty. A country that has a low score of uncertainty avoidance has a high tolerance level of risk in its social character.

\section{H6: Use of fintech market aggregator services (UF) has a positive effect on user satisfaction (US)}

Based on hypothesis testing on the table above show that $\mathrm{H}_{6}$ was accepted (p-value $<0.005$ ). It is showed that the experience of the user affected user satisfaction. It is supported by the result of interviews with some FMA providers that user know their need and benefit of using FMA services. And the user will feel satisfied after using the FMA services. It is also supported by previous research shown that the use of Regional Financial Information System Implementation has a direct impact on user satisfaction [25].

\section{Summary}

The conclusion of the study indicated that only half of respondents already use the FMA services. While respondents who already use the FMA services feel that FMA services enhancing the productivity, effectiveness, simplifying the process, and increasing the quality of services in getting bank and non-bank product. Easy to use, customer service availability, easy feature, and social influence also support the reasons to use FMA services.

While facilitating conditions had no significant impact on the use of FMA services. It is because most of the respondents have a young age and get used to accessing various kinds of applications and websites. Enhancement on internet access also helps the user to easily get the internet to access the website and application of FMA. FAQ (Frequently Asked Questions) features also help to answer some general questions. Trust also had no significant impact on the use of FMA services because social influence is enough to support users to use FMA services. But FMA and other fintech need to educate users that it's important to know if the fintech already protected by formal institutions and governance to avoid fraud and privacy misuse.

\section{Implications/Limitations and Suggestions for Further Research}

Performance expectancy, effort expectancy, and social influence are the main determinants when users decide to use fintech market aggregator services. The implications that could be used for FMA services to increase the usage of FMA user are adding some features like "article" which give information about the bank and non-bank product and the requirement document needed. Feature "apply" could also help user to apply online the bank and non-bank product. And feature "filter" which can be modified by user could increase the user effectiveness to find the bank and nonbank product as user's need. FMA could also add feature "comparison" to compare the product information. Feature 
"chatbot" which could help customer service to answer some general question. And feature "upload document" to upload the document online and more effective. While in social influence, FMA could make a "referral code" program that allow user to invite friends or family to use FMA.

The limitation of this research are missing another variable for $28.4 \%$ that could explain the use of fintech market aggregator. And another variable for $54.8 \%$ that could explain user satisfaction. Other limitations are limited research about fintech market aggregator and this research discuss fintech market aggregator as general.

Therefore, further research should consider another variable that could increase the $\mathrm{R}^{2}$ value. Hedonic motivation could be used as another variable to explain the use of fintech market aggregator. While responsiveness and empathy could be used as another variable to explain the user satisfaction. The next research could also use another theory like TAM to support the FMA research and discuss specific product of FMA.

\section{References}

[1] World Bank, "The Global Findex Database 2014: Measuring Financial Inclusion around the World," no. April, 2015.

[2] G. J. Siahaan, "Fintech Picu Daya Saing,” J. Adm. Bisnis, vol. 61, no. 1, pp. 215-223, 2017, [Online]. Available: www.ojk.go.id.

[3] Alliance for Financial Inclusion, "Digital Financial Services Basic Terminology," no. 19, p. 12, 2016, [Online]. Available: http://www.afi-global.org/sites/default/files/publications/2016-08/Guideline Note-19 DFS-Terminology.pdf.

[4] T. D. I. Ojk and D. Dana, "Penyelenggara ikd tercatat di ojk," 2020.

[5] OJK, “Daftar Penyelenggara IKD Tercatat Juli 2019,” 2019.

[6] Venkatesh, "USER ACCEPTANCE OF INFORMATION TECHNOLOGY: TOWARD A UNIFIED VIEW," vol. 27 No 3, pp. 425-478, 2003.

[7] G. Chikondi Daka and J. Phiri, "Factors Driving the Adoption of E-banking Services Based on the UTAUT Model," Int. J. Bus. Manag., vol. 14, no. 6, p. 43, 2019, doi: 10.5539/ijbm.v14n6p43.

[8] M. Kurfal1, A. Arifoğlu, G. Tokdemir, and Y. Paçin, "Adoption of e-government services in Turkey," Comput. Human Behav., vol. 66, pp. 168-178, 2017, doi: 10.1016/j.chb.2016.09.041.

[9] J. H. Lee and C. H. Song, "Effects of trust and perceived risk on user acceptance of a new technology service," Soc. Behav. Pers., vol. 41, no. 4, pp. 587-597, 2013, doi: 10.2224/sbp.2013.41.4.587.

[10] I. Arpaci, "Understanding and predicting students' intention to use mobile cloud storage services," Comput. Human Behav., vol. 58, pp. 150-157, 2016, doi: 10.1016/j.chb.2015.12.067.

[11] F. F. O. Malaquias and Y. Hwang, "Trust in mobile banking under conditions of information asymmetry: Empirical evidence from Brazil," Inf. Dev., vol. 32, no. 5, pp. 1600-1612, 2016, doi: $10.1177 / 0266666915616164$.

[12] P. Pavlou and D. Gefen, "Building Effective Online Marketplaces with Institution-Based Trust BUILDING EFFECTIVE ONLINE MARKETPLACES WITH INSTITUTION-BASED TRUST,” Int. Conf. Inf. Syst., pp. 667-675, 2002, [Online]. Available: http://aisel.aisnet.org/icis2002/63.

[13] C. M. Chiu, C. S. Chiu, and H. C. Chang, "Examining the integrated influence of fairness and quality on learners' satisfaction and Web-based learning continuance intention," Inf. Syst. J., vol. 17, no. 3, pp. 271-287, 2007, doi: 10.1111/j.1365-2575.2007.00238.x.

[14] P. Kotler and G. Armstrong, Principles of Marketing, Seventeenth Edition. 2018.

[15] F. Mohsan, M. M. Nawaz, M. S. Khan, Z. Shaukat, and N. Aslam, "Impact of customer satisfaction on customer loyalty and intentions to switch : evidence from banking sector of Pakistan," Int. J. Bus. Soc. Sci., vol. 2, no. 16, pp. 263-270, 2011.

[16] R. L. Oliver, Satisfaction: A behavioral perspective on the consumer. Armonk: NY: M.E. Sharpe, 2010.

[17] M. Hair, J. F., Hult, G. T. M., Ringle, C. M., \& Sarstedt, "A Primer on Partial Least Squares Structural Equation Modeling (PLS-SEM). Thousand Oaks,” Sage, p. 165, 2013. 
[18] J. J. N. Prihanto, "Transformasi Digital Industri Perhotelan: Studi pada Industri Perhotelan di Daerah Istimewa Jogyakarta," vol. 13, no. 2, 2018.

[19] K. A. Sudiyono, T. Mursitama, B. Simatupang, and M. Hamsal, "The Governance of Public-Private Ties Model: How to Govern the PPPs Infrastructure Project Effectively (An Indonesia Case)," vol. 36, no. Icbmr, pp. 347-357, 2017, doi: 10.2991/icbmr-17.2017.32.

[20] N. A. Farabi, “Analisis Penerapan Sistem informasi ZISW Dengan Menggunakan Metode UTAUT," Indones. J. Comput. Inf. Technol., vol. 1, no. 2, pp. 71-79, 2016.

[21] Hofstede-Insights, "Hofstede-Insights," 2020. https://www.hofstede-insights.com/.

[22] H.-Y. Lin, M.-H. Wang, and H.-T. Chen, "Determinants for Consumer Adoption of Mobile Payment Technology," Int. J. e-Education, e-Business, e-Management e-Learning, vol. 9, no. 3, pp. 146-159, 2019, doi: 10.17706/ijeeee.2019.9.3.146-159.

[23] J. Miadinovic and H. Xiang, "A Study on Factors Affecting the Behavioral Intention to use Mobile Shopping Fashion Apps in Sweden," pp. 1-75, 2016, [Online]. Available: http://www.divaportal.org/smash/get/diva2:933382/FULLTEXT01.pdf.

[24] A. P. Hendratmoko, "Faktor-Faktor Yang Memengaruhi Individu Dalam Menggunakan Peer To Peer Lending Dan Equity Crowd Funding Di Dki Jakarta," Fakt. Yang Memengaruhi Individu Dalam Menggunakan Peer To Peer Lend. Dan Equity Crowd Funding Di Dki Jakarta, vol. 9, no. November, 2019.

[25] A. Hormati, "Pengujian Model Unified Theory of Acceptance and Use of Technology Dalam Pemanfaatan," J. Akunt. Multiparadigma, vol. 3, no. April, pp. 1-24, 2012. 